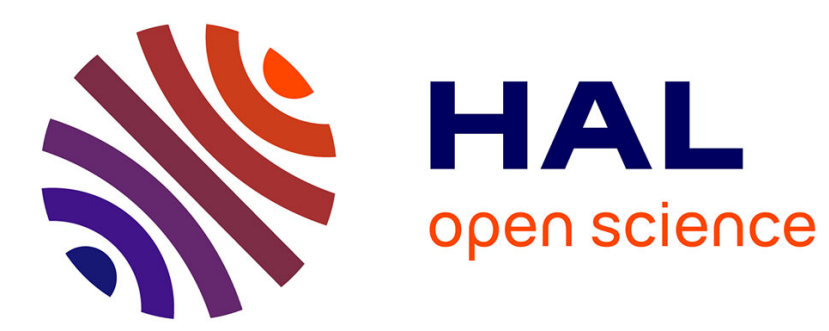

\title{
From JMV-1843 to Macrilen TM
}

Jean Martinez, Jean-Alain Fehrentz

\section{To cite this version:}

Jean Martinez, Jean-Alain Fehrentz. From JMV-1843 to Macrilen TM. Australian Journal of Chemistry, In press, 10.1071/CH19530 . hal-02456019

\section{HAL Id: hal-02456019 https://hal.science/hal-02456019}

Submitted on 27 Jan 2020

HAL is a multi-disciplinary open access archive for the deposit and dissemination of scientific research documents, whether they are published or not. The documents may come from teaching and research institutions in France or abroad, or from public or private research centers.
L'archive ouverte pluridisciplinaire HAL, est destinée au dépôt et à la diffusion de documents scientifiques de niveau recherche, publiés ou non, émanant des établissements d'enseignement et de recherche français ou étrangers, des laboratoires publics ou privés. 


\title{
From JMV-1843 to Macrilen ${ }^{\mathrm{TM}}$
}

Jean Martinez*, Jean-Alain Fehrentz

Institut des Biomolécules Max Mousseron (IBMM), UMR CNRS 4257, Université Montpellier, ENSCM, Montpellier, France.

Email address: jean.martinez@umontpellier.fr

\begin{abstract}
Growth hormone deficiency (GHD) is a severe pathology that greatly affects the quality of life, and increases morbidity and mortality of patients owing to the augmentation of cardiovascular events. Treatment of GHD is challenging, mainly because there is no specific characteristic sign or symptom that can be used to make a clear diagnosis. There is need for an unequivocal diagnosis of GHD to avoid unnecessary treatment with $\mathrm{GH}$, because the available provocative tests (GH stimulation tests) are not specific and sensitive enough, and are contraindicated in some patients.

Ghrelin is an endogenous peptide that stimulates GH secretion by interacting with a G-proteincoupled receptor named ghrelin receptor (GH secretagogue receptor 1a, GHS-R1a). Given this, a GH stimulation test using ghrelin or its analogues appears to be attractive. In this paper, a modified tripeptide first named JMV-1843 in the laboratory is briefly presented. It is potent and selective in stimulating the release of $\mathrm{GH}$ and is orally active. It has been recently commercialized for the diagnosis of adult growth hormone deficiency under the tradename Macrilen ${ }^{\mathrm{TM}}$. The test using this compound appears to be reliable, well tolerated and simple.
\end{abstract}

\section{Introduction}

Adult growth hormone deficiency (AGHD) is usually caused by childhood GHD or by various conditions of the hypothalamus and pituitary gland resulting from tumours and their treatments, including surgery and irradiation [1]. AGHD results in severe morbidity associated with reduced quality of life, including reduced exercise tolerance as a consequence of fat mass increase, osteopenia, glucose intolerance and insulin resistance, as well as altered cardiovascular functions, which all decrease survival [2]. In the United States, approximately 60000 people have been diagnosed with AGHD, while 6000 new cases are reported each year [3]. In Europe, about 51000 adults are estimated to have been diagnosed with GHD [4]. However, because the symptoms are non-specific and there is no well-defined clinical marker of GHD in adults, a method to diagnose AGHD is necessary.

\section{Results and Discussion}

The detection of GHD is challenging, because growth hormone $(\mathrm{GH})$ secretion occurs episodically in a pulsatile pattern, and is influenced by age, gender and body mass index $[5,6]$. Consequently, the diagnosis should be based on an appropriate provocative GH stimulation test (GHST) using a stimulus that can rapidly induce release of $\mathrm{GH}$, which can be detected in blood samples [7]. 
There are six main tests for evaluating AGHD [8,9] including the insulin tolerance test (ITT), the combined arginine-GH-releasing hormone (ARG-GHRH) test and the glucagon test, which are used for adults. The ITT is considered to be the reference test, although it is limited to certain patients because of the risk of hypoglycaemia; patients must not have ischaemic heart disease or seizures [8,9]. However, all GHSTs have limitations in the diagnosis of AGHD concerning their sensitivity, specificity and/or reproducibility. In addition, they usually require parenteral administration by trained personnel, with a follow-up period in monitored facilities.

Several factors influence GH release. Among them, a potent 28 -amino acid acylated peptide named ghrelin (Figure 1) produced mainly by the stomach, was isolated and identified by Kojima et al. in 1999 [10]. By binding to the 7-transmembrane G-protein-coupled receptor (GHS-R1a) [11], ghrelin induces GH secretion. The wide range of pharmacological and physiological properties of ghrelin have been described [12].

Since 1996, in collaboration with Dr R. Deghenghi, Europeptides (France) and several laboratories in Europe, including the Universities of Milano and Torino (Italy), we have been involved in a European programme (Peptido, Eureka ${ }^{\circ} 1923$ ) to design and synthesize peptides and mimetics able to stimulate GH release. The goal of this project was to identify an active compound as short as possible, selective, stable and orally effective, with possible therapeutic applications including the diagnostic test for detection of AGHD among GH-related disorders, and in some non-GH-related disorders associated with the wide range of biological activities of ghrelin $[13,14]$.

In our laboratory, we have synthesized a series of analogues based on compound EP-51389, a potent GH-releasing peptide developed by R. Deghenghi at Europeptides (Figure 1) [15]. Based on our previous studies on gastrin [16] and bombesin [17], we have designed and synthesized a series of modified peptides, among them compound JMV-1843 (Figure 1), which, according to its pharmacological profile, was selected for further studies [18].

The chemical characteristics of JMV-1843 reside in its C-terminal formyl-amino function that mimics the C-terminal amide of EP-51389, which according to our previous studies on bombesin analogues should confer a certain degree of oral bioavailability [17], and on a gem-diamino tryptophan that improves enzymatic resistance [16].

Tested in competition binding assays using LLC PK-1 cells transiently overexpressing the cloned hGHS-R1a human receptor [18], human pituitary glands and hypothalamic membranes expressing the hGHS-R1a receptor [19], compound JMV-1843 displaced ${ }^{125}$ I-labelled ghrelin in a dose-dependent manner and with high affinity. It exhibited approximately the same potency as ghrelin (in the $10 \mathrm{nM}$ range) and the potent hexapeptide ghrelin agonist hexarelin [20], a wellcharacterized potent growth hormone secretagogue (GHS).

In vivo, JMV-1843 administered subcutaneously (s.c.) in rats was able to stimulate $\mathrm{GH}$ release dose dependently to the same extent as hexarelin. In dogs, JMV-1843 administered intravenously (i.v.) or given orally $(1 \mathrm{mg} / \mathrm{kg}$ ) stimulated significant GH release [18]. Compound JMV-1843 (then named EP1572) was then given i.v. $(1.0 \mu \mathrm{g} / \mathrm{kg}$ as a bolus) and orally $(0.06,0.125,0.25$ and 
$0.5 \mathrm{mg} / \mathrm{kg}$ body weight) to two young male volunteers. At a dose of $0.06 \mathrm{mg} / \mathrm{kg}$ body weight given orally, JMV-1843 induced a remarkable and prompt increase in GH levels $[19,21]$ that persisted for 3 hours. A further randomized, placebo-controlled study was conducted on 36 healthy volunteer male participants to evaluate both the pharmacological profile and $\mathrm{GH}-$ releasing activity of increasing single oral doses of JMV-1843 [22].

The results of this study indicated that oral administration of JMV $-1843(0.5 \mathrm{mg} / \mathrm{kg})$ to healthy male volunteers resulted in a rapid and dose-dependent release of $\mathrm{GH}$, with maximal $\mathrm{GH}$ release between 50 and 75 minutes, which lasted for $>2$ hours after administration. A significant GH release was detected even at a dose of $0.125 \mathrm{mg} / \mathrm{kg}$.

No adverse effects were observed and, in contrast to ghrelin, there was only a marginal effect on prolactin levels, while adrenocorticotropin (ACTH), cortisol, and ghrelin levels, as well as plasma concentrations of glucose and insulin, were not significantly affected.

Although far from being proven, this selectivity could be the consequence of the activation of different $G$ proteins that modulate different intracellular signalling pathways and induce different biological responses and physiological processes in a given tissue. This specific G-protein activation could be the result of either homodimerization of the GHS-R1a or of its heterodimerization with another G-protein-coupled receptor expressed in the same tissue [23, 24].

According to these preliminary results, Aetherna Zentaris selected compound JMV-1843 for further clinical investigation in 25 hospitals around the world: 377 participants were enrolled for the phase 3 clinical trials of oral administration of macimorelin (JMV-1843) as a diagnostic agent for AGHD.

Although the oral bioavailability of macimorelin is not high, the results of this multicentre study indicate that, at a dose of $0.5 \mathrm{mg} / \mathrm{kg}$ body weight, macimorelin was efficient in stimulating $\mathrm{GH}$ release in the blood to a level approximately 1.4-fold higher than with the ITT, and it was well tolerated. It was concluded that macimorelin was useful in the diagnosis of AGHD; usually after collection from the patients of four blood samples, at 30,45, 60, and 90 minutes, to reduce the risk of false-positive results. There was no need of an extended follow-up period, and no need of parenteral administration [25].

The most common adverse effects associated with macimorelin, which appeared in $<5 \%$ of patients, were a change in the sense of taste, headache, diarrhoea, nausea and fatigue. During the initial phase 3 clinical trial, a drug-related alteration of cardiac rhythm (QT prolongation) was observed in one patient, which disappeared within $24 \mathrm{~h}$. This participant had been taking citalopram, a drug known to be associated with QT prolongation. Accordingly, the use of macimorelin with drugs known to induce torsades de pointes, including antipsychotic products, should be contraindicated. This observation required a second phase 3 clinical investigation more particularly oriented towards this adverse effect. Finally, a single orally administered dose of macimorelin (usually $0.5 \mathrm{mg} / \mathrm{kg}$ ) was recognized not to represent a particular risk and to be acceptable. In addition, because cytochrome P450 (CYP3A4) is involved in the metabolic degradation of macimorelin, one should be aware of the potential for false positives when diagnosing AGHD in patients treated with CYP3A4 inducers. 
In summary, these clinical trials demonstrated that orally available macimorelin was reliable in the diagnosis of AGHD, with minimal adverse effects when compared with the other tests available, and with an acceptable safety profile. Details of the phase 3 clinical trials are available at https://www.clinicaltrials.gov/ct2/show/NCT02558829?term=macimorelin. However, the use of macimorelin for young patients and for adults with extreme and morbid obesity remains to be demonstrated [26].

In December 2017, following the successful clinical trial results, the US Food and Drug Administration (FDA) granted their approval for commercialization of macimorelin in the USA and Canada, under the tradename Macrilen ${ }^{\mathrm{TM}}$, for the diagnosis of AGHD [27]. In January 2019, the European Medicines Agency (EMA) also approved the marketing authorization for macimorelin for the diagnosis of AGHD.

A summary of the most significant events that occurred during the development of JMV-1843 to macimorelin and Macrilen ${ }^{\mathrm{TM}}$ are reported in Table 1.

\section{Conclusion}

Macimorelin (Macrilen ${ }^{\mathrm{TM}}$ ) is a novel active $\mathrm{GH}$ secretagogue that has an interesting pharmacological and clinical profile for diagnosis of AGHD, with several advantages compared with the established tests. Macimorelin appears to provide a simple and accurate diagnosis of AGHD, which has remained a challenge, and which is required for identification of patients that need GH treatment. The diagnosis of AGHD with macimorelin is highly competitive with the existing tests, which lack sensitivity and selectivity, and for which the parenteral administration route and the follow-up after administration of the drug are restrictive.

In addition, taking into account the range of biological activities of ghrelin, macimorelin can be envisioned in other clinical applications. These include treatment of growth retardation in children, and cachexia associated with chronic diseases such as AIDS and cancer. In this respect, a phase $1 / 2$ study started recently, comprising an open-label clinical trial involving 24 children and adolescents under the age of 18 years. Macimorelin is also being used in a phase 2A clinical trial for the treatment of cancer-induced cachexia. However, whether or not macimorelin is beneficial in clinical applications other than the diagnosis of AGHD remains to be demonstrated.

\section{Acknowledgments}

Studies performed at the University of Montpellier were supported by CNRS, University of Montpellier, EU Eureka Project (Peptido Project 1923), Europeptides and Aetherna Zentaris. The authors would also like to thank all the individuals that were involved in the JMV-1843 project allowing the compound to reach the market.

\section{Conflict of interests}

The authors declare no conflicts of interest. 


\section{References}

[1] A.S. Bates, W. Van’t Hoff, P.J. Jones, R.N. Clayton, J. Clin. Endocrinol. Metab. 1996, 81, 169.

[2] P.V. Carroll, E.R. Christ, B.A. Bengtsson, L. Carlsson, J.S. Christiansen, D. Clemmons, R. Hintz, K. Ho, Z. Laron, P. Sizonenko, P.H. Sönksen, T. Tanaka, M. Thorner, J. Clin. Endocrinol. Metab. 1998, 83, 382.

[3] Communication AEterna Zentaris Inc, Quebec City, August 7, 2012.

[4] K. Stochholm, C.H. Gravholt, T. Laursen, J.O. Jørgensen, P. Laurberg, M. Andersen, L. Ø. Kristensen, U. Feldt-Rasmussen, J. S. Christiansen, M. Frydenberg, A. Green, Eur. J. Endocrinol. 2006, 155, 61.

[5] K.C.J. Yuen, N.A. Tritos, S.L. Samson, A.R. Hoffman, L. Katznelson, Endocr. Pract. 2016, 22, 1235.

[6] S. Melmed, J Clin Endocrinol Metab. 2013, 98, 2187.

[7] K.K. Ho, Eur. J. Endocrinol. 2007, 157, 695.

[8] V. Agrawal, J.M. Garcia, Expert Review of Molecular Diagnostics 2014, 14, 647.

[9] B.M.K. Biller, M.H. Samuels, A. Zagar, D.M. Cook, B.M. Arafah, V. Bonert, S. Stavrou, D.L. Kleinberg, J.J. Chipman, M.L. Hartman, J. Clin. Endocrinol. Metab. 2002, 87, 2067.

[10] M. Kojima, H. Hosoda, Y. Date, M. Nakazato, H. Matsuo, K. Kangawa, Nature, 1999, 402, 656.

[11] A.D. Howard, S.D. Feighner, D.F. Cully, J.P. Arena, P.A. Liberator, C.Y. Rosemblum, M. Hamelin, D.L. Hreniuk, O.C. Palyha, J. Anderson, P.S. Paress, et al. Science, 1996, $273,974$.

[12] A.J. van der Lely, M. Tschop, M.L. Heiman, E. Ghigo, Endocr. Rev. 2004, 25, 426.

[13] G. Muccioli, M. Tschöp, M. Papotti, R. Deghenghi, M. Heiman, E. Ghigo, Eur. J. Pharmacol. 2002, 440, 235.

[14] E. Arvat, M. Maccario, L. Di Vito, F. Broglio, A. Benso, C. Gottero, M. Papotti, G. Muccioli, C. Dieguez, F.F. Casanueva, R. Deghenghi, F. Camanni, E. Ghigo, J. Clin. Endocrinol. Metab. 2001, 86, 1169.

[15] R. Deghenghi, Acta Paediatr. 1997, Suppl. 423, 85.

[16] M. Rodriguez, P. Dubreuil, J-P Bali, J. Martinez, J. Med. Chem., 1987, 30, 758.

[17] Unpublished results.

[18] V. Guerlavais, D. Boeglin, D. Mousseaux, C. Oiry, A. Heitz, R. Deghenghi, V. Locatelli, A. Torsello, C. Ghe, F. Catapano, G. Muccioli, J-C. Galleyrand, J-A. Fehrentz, J. Martinez, J. Med. Chem. 2003, 46, 1191.

[19] F. Broglio, F. Boutignon, A. Benso, C. Gottero, F. Prodam, E. Arvat, C. Ghe, F. Catapano, A. Torsello, V. Locatelli, G. Muccioli, D. Boeglin, V. Guerlavais, J-A. Fehrentz, J. Martinez, E. Ghigo, R. Deghenghi, J. Endocrinol. Investig. 2002, 25, RC26.

[20] E. Arvat, J. Ramunni, R. Giordano, B. Maccagno, F. Broglio, A. Benso, R. Deghenghi, E. Ghigo, J. Endocrinol. Invest. 1999, 22, 23.

[21] B. Holst, E. Brandt, A. Bach, A. Heding, T.W. Schawrtz, Mol. Endocrinol. 2005, 19, 2400.

[22] F. Piccoli, L. Degen, C. MacLean, S. Peter, L. Baselgia, F. Larsen, C. Beglinger, J. Drewe, J. Clinical Endocrinol. \& Metabol. 2007, 92, 1814.

[23] S. Mary, J-A. Fehrentz, M. Damian, G. Gaibelet, H. Orcel, P. Verdié, B. Mouillac, J. Martinez, J. Marie, J-L. Banères, J. Biol. Chem. 2013, 288, 24656.

[24] M. Damian, V. Pons, P. Renault, C. M'Kadmi, B. Delort, L. Hartmann, A. I. Kaya, M. Louet, D. Gagne, K.B.H. Salah, S. Denoyelle, G. Ferry, J.A. Boutin, R. Wagner, J-A. Fehrentz, J. Martinez, J. Marie, N. Floquet, C. Galès, S. Mary, H.E. Hamm, J-L. Banères, Proc. Natl. Acad. 
Sci. USA 2018, 115, 4501.

[25] European Medicines Agency, Science Medicines Health, EMA/CHMP/845216/2018, Committee for Medicinal Products for Human Use (CHMP), 15 November 2018.

[26] G.R. Gabreanu, Discoveries 2018, 6 (1), e82.

[27] US Food and Drug Administration. NDA approval. NDA 205598. https://www.accessdata.fda.gov/drugsatfda docs/label/2017/205598s000lbl.pdf, December 20, 2017. Accessed: March 31, 2018. 


\section{Table 1. From compound JMV-1843 to Macimorelin/Macrilen ${ }^{\mathrm{TM}}$}

January 1996: European program Peptido (Eureka n¹923).

1999: Design and synthesis of compound JMV-1843 [DAPP (IBMM-Montpellier, France)].

1999-2000: In vitro pharmacological evaluations of compound JMV-1843 [DAPP (IBMMMontpellier, France)]; in vivo pharmacological evaluations of JMV-1843 in several species (University of Milano, Italy).

June 2000: Provisional application $\mathrm{N}^{\circ}$ 09/880,498, filed June 2000, Patent (US 6,861,409 B2 filed June 2001), Growth Hormone Secretagogues"", Jean Martinez, Jean-Alain Fehrentz, Vincent Guerlavais.

November 2001: International patent application filed (PCT/EP01/06717, WO 01/96300 A1).

May 2002: Publication of the first results of JMV-1843 (EP1572) orally administered to humans (healthy volunteers).

July 2002: Patent licensed to Ardana Bioscience.

Filed May 2004: Patent US 7,297,681 B2, Growth Hormone Secretagogues, Jean Martinez, Jean-Alain Fehrentz, Vincent Guerlavais.

April 2005: Phase 1 clinical trials of JMV-1843 (ARD-07).

Filed February 2007: Patent US 8,192,719 B2, PCT WO2007/093820, Methods and Kits to Diagnose Growth Hormone Deficiency by Oral Administration of EP1572 or EP1573 Compounds, Finn Larsen.

May 2007: JMV-1843 (Macimorelin/Solorel) is recognized as an orphan drug by the FDA.

July 2008: Phase 2 clinical trials. Ardana sold the licence of JMV-1843 to Æterna-Zentaris.

2010: Start of phase 3 clinical trials of JMV-1843 (AEZS-130, Macimorelin).

2013: Publication of phase 3 clinical trials of JMV-1843 (Solorel, Macimorelin).

November 2013: Application for the Marketing Authorization of JMV-1843 (Macrilen ${ }^{\mathrm{TM}}$ ) to FDA.

November 2014: Rejection by FDA.

2015: Start of confirmatory phase 3 clinical trial.

June 2017: New application for marketing authorization to FDA

March 2017: The European Medicines Agency (EMA) accepted the paediatric investigation plan ("PIP") of Macrilen/Macimorelin.

November 2017: European Medicines Agency (EMA) agreed to evaluate the application for the marketing authorization of Macrilen/Macimorelin.

December 2017: The US FDA granted marketing approval for Macrilen ${ }^{\text {TM }}$ in the USA and Canada as an oral GHS receptor agonist, to be used in the diagnosis of patients with AGHD.

January 2018: Aeterna Zentaris entered into a licence and assignment agreement with GmbH Strongbridge, Ireland, from which it acquired the US and Canadian rights to Macrilen ${ }^{\mathrm{TM}}$ (Macimorelin). 
October 31, 2018: Novo Nordisk acquired the rights of Macrilen ${ }^{\mathrm{TM}}$ (Macimorelin) in the USA and Canada.

November 2018: The Committee for Medicinal Products for Human Use (CHMP) gave a positive opinion of Macimorelin (Macrilen $^{\mathrm{TM}}$ ).

January 2019: The EMA granted marketing authorization for Macimorelin (Macrilen ${ }^{\mathrm{TM}}$ ).

February 2019: Phase $1 / 2$ paediatric clinical trial initiated with Macrilen ${ }^{\circledR}$ (Macimorelin) by Aeterna Zentaris GmbH and Novo Nordisk. 
Figure 1. Structure of ghrelin, hexarelin, EP-51389 and JMV-1843

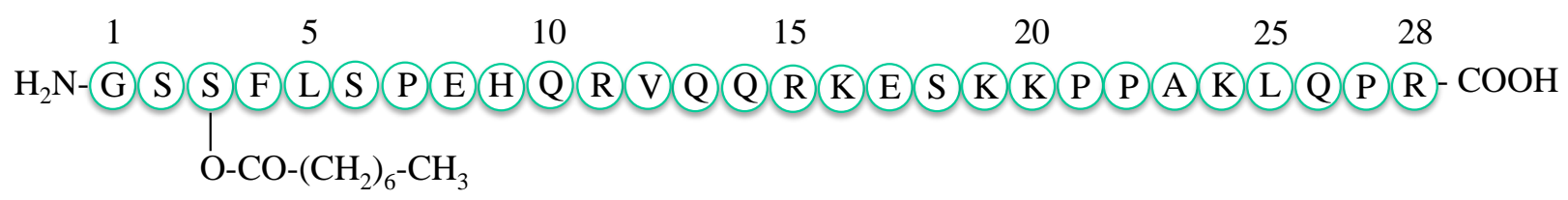

\section{Ghrelin}

H-His-D(2Me)Trp-Ala-Trp-DPhe-Lys- $\mathrm{NH}_{2} \quad$ Hexarelin

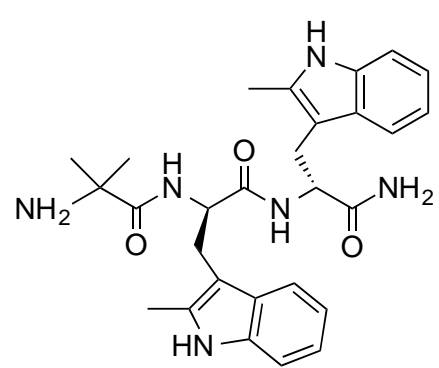

EP-51389

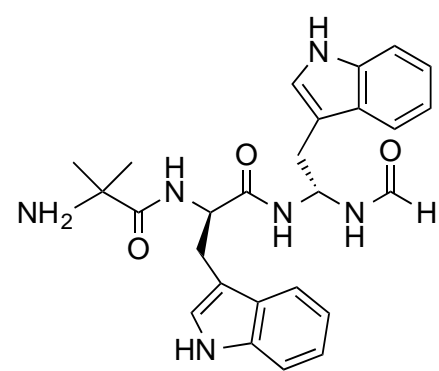

JMV-1843

JMV-1843 synonyms: JMV1843; JMV 1843; ARD-07, AEZS-130; AEZS 130; AEZS130; EP-1572; EP 1572; EP1572; EP-01572; Macimorelin; Macrilen ${ }^{\text {TM; }}$ AibDTrpDgTrpCHO. 


\section{TOC}

JMV-1843 (tradename Macrilen ${ }^{\mathrm{TM}}$ ) is a modified tripeptide, which stimulates the release of growth hormone $(\mathrm{GH})$ by interacting with the ghrelin receptor. Macrilen ${ }^{\mathrm{TM}}$ is the first orally available compound commercialized for diagnosing adult growth hormone deficiency (EGHD). The test appears to be reliable, well tolerated and simple. The story of JMV-1843 in the laboratory to Macrilen ${ }^{\mathrm{TM}}$ in the market is summarized. 